\title{
Derivative neologisms as sociocultural dominants in the Russian and Czech languages of the modern period
}

\author{
Nadezhda Samylicheva ${ }^{1 *}$, and Jiř́ Gazda ${ }^{2}$ \\ ${ }^{1}$ Lobachevsky State University of Nizhny Novgorod, 23 Prospekt Gagarina, Nizhny Novgorod , \\ 603950, Russian Federation \\ ${ }^{2}$ Masaryk University, Arna Nováka 1, Brno, 602 00, Czech Republic
}

\begin{abstract}
The article is devoted to the analysis of word-formation neologisms in modern media speech from the point of view of their sociocultural characteristics during the COVID-19 pandemic (on Russian and Czech internet speech). In derivational processes, socially significant, socalled key words play an important role, forming a special socio-cultural space, thereby becoming a kind of dominants in modern speech. Such lexemes give a life to a big quantity of derived units. So, neologisms with initial words reflecting the situation of a pandemic in 2020 in modern Russian and Czech society, clearly enough evidence of public attitudes - a negative assessment and rejection of what is happening and at the same time irony and a language game.
\end{abstract}

\section{Introduction}

The relevance of this research is provided by the popularity of occasional word formation that has actively increased in the past few decades. Despite the impressive list of literature devoted to the study of new words, neologisms still deserve detailed study by researchers, especially from the point of view of reflecting actual social realities in them.

The topic of casualness is much broader than it seems at first glance. Neologism can be viewed not only from a purely linguistic point of view. For example, it is worth trying to study neologisms in accordance with their sociological orientation.

Now the mass media, the Internet amaze with the scale of the spread of occasional words. What is the reason for such popularity of non-standard word formation? The main goal of creating neologisms is to realize the creative potential of the writer and activate the attention of the reader. The author resorts to creating a new word, since the existing words do not accurately reflect the phenomenon, object or situation described by him.

The modern world is in a sense characterized by an overabundance of information. Neologisms are an effective tool that helps to draw attention to the very text in which they arise, to single out a given speech work from the huge flow of the existing information

*Corresponding author: nadezhda.samylicheva@yandex.ru 
array. The language of the mass media can now be compared to the economic market: as each seller fights for his buyer, so each author fights for his reader.

The world and man are rapidly changing, spinning the funnel of changes in all areas that exist in modern reality. The language system is no exception: it is subject to constant development and various transformations that occur "in response" to the surrounding transformations. For example, now the whole world is watching a fascinating performance called "Coronavirus", and creative individuals have already shown their talents in the formation of occasional words that capaciously characterize aspects of the "new" human life.

Purpose of the study is to analyze word-formation neologisms in modern media speech in terms of their socio-cultural characteristics during the COVID-19 pandemic (on Russian and Czech internet speech).

The high degree of expressiveness and evaluativeness characteristic of the language of modern media is manifested quite clearly at the level of word formation. Neologisms, in which the inner form appears in the most naked form, are also an indicator and exponent of certain value attitudes in society. In derivational processes, socially significant, so-called key words [1] play an important role, forming a special socio-cultural space, thereby becoming a kind of dominants in modern speech $[2,3]$. Such lexemes become the basis for the production of many new units. [4].

So, neologisms with initial words reflecting the situation of the pandemic in 2020 in modern Russian and Czech society, clearly enough evidence of public sentiments - a negative assessment and rejection of what is happening and at the same time irony and a language game.

\section{Background}

\subsection{Neologisms in modern mass media}

Today mass media is the most sensitive registrar of new words, meanings, and phrases. It reflects the shifts that are taking place in all spheres of society much faster than all other genres of written speech, and in most cases is the first written source that records the birth of new words, meanings and expressions that claim to be included in common vocabulary. The media and language in general are very closely related: analyzing internet articles, one can notice many existing development trends and processes of change in the modern literary language.

The language of the media is a new formative variety of language that has the greatest influence on the system of national languages and at the same time is the litmus that is the first to detect the trends emerging in the development of this system.

The effect of influencing the reader, which is achieved through the creation and use of neologisms in his speech, is similar to a state of shock, breaking the template, shaking. Usual words are difficult to attract attention, contemporaries to some extent ceased to be surprised. Word-makers use occasional word formation to stir up, wake up society and give free rein to feelings.

"Day after day, right before our eyes, this linguistic restructuring is taking place, the impetus for which has been and remains the socio-economic restructuring. What do we see when we open the next page of any weekly newspaper or the cover of a glossy women's magazine? Countless innovations, many borrowings, non-standard word formations and phrases, sophisticated metaphoricity of the so-called media language" [5].

Analyzing the language of modern media, one can notice that occasional word formation is actively developing in areas of greatest interest to public opinion [6]. The mass 
media was swept by a wave of neologisms and the number of situational neologisms on the pages of newspapers and magazines is growing day by day. According to A.D. Yudina, neoderivates reflect "the history of the disease of our society": "Occasionalisms are snapshots of living Russian speech. They are evidence of how the reality around us is reflected in the public consciousness, and what it is, this reality" [6].

\subsection{Ways of word formation of neologisms in Russian and Czech media languages during the coronavirus pandemic}

Word creation in Russian and Czech during the pandemic quite clearly demonstrated the fact how strongly the features of analyticism are manifested in modern word formation in these languages.

Most of the new words are created by pure compounding or by means of occasional word formation - various types of hybridization.

Hybridization is similar to the compounding method but occurs in violation of derivational norms. The result of hybridization is a complex word of an evaluative nature with an attitude towards a language game.

\subsection{Objects and methods}

In the selection of the material, the method of continuous sampling from electronic mass media in 2020 was used. To analyze the material within the framework of the structuralfunctional and pragmatic principle of description, the methods of word-formation and structural-semantic analysis were used to determine the derivational structure of neologisms and the characteristics of their value, as well as methods of pragmatic analysis, discourse analysis to identify the specifics of the functioning of neologisms in media discourse.

Also we should mention, that "a look at the native language through the prism of another, related language opens up great opportunities not only for identifying the specifics of one's own language, but also for establishing uniformity, similarity, and typological features inherent in languages. Bilingual comparison and description of similar and differentiated linguistic phenomena is also of great linguodidactic significance, aiming at the fact that, while studying another Slavic language, you need to look at it from the point of view of a different linguistic culture" [7].

\section{Results}

In media discourse, the choice of linguistic means, including word-formation ones, "is associated with an assessment aimed at influencing the addressee, with a system of value orientation, when conceptual, social, imaginative and emotional characteristics come to the fore" [8].

When studying active processes in Slavic word formation, one can notice that the socalled "key words of the epoch" play a large role in modern word creation. "Occasionalisms are often created in order to show the true essence of this or that phenomenon. Occasionalisms name phenomena of varying degrees of significance" [1]. In this aspect, the formation of neologisms based on keywords is interesting and significant.

These "keywords" generate whole groups of one-root words (word-building nests and word-building paradigms). The activity of keywords affects not only their word-formative potential, but also the relationship with other words, actualizing certain relationships between words in the lexical system of the language. According to E.A. Zemskaya, "key" should be considered "words denoting phenomena and concepts that are in the focus of 
social attention" [1]. Key words can be considered evaluative dominants of modern reality, one of the manifestations of a linguistic personality.

One of the most important components of the linguistic picture of the world is "value dominants, the totality of which forms a certain type of culture, supported and preserved in the language" [2]. According to V.N. Telia, everything that can be interpreted in terms of evaluativeness, belongs to the circle of national culture [9]. Evaluative dominants, representing the orientation of communicants, are closely related to the content aspect of communication and the system of value ideas that exist in society. Values are largely determined by ideology, social institutions, beliefs, needs [10]. Essential for understanding the ongoing processes and their results, tracked in the language, is recognized their connection with changes in public consciousness, ideological reorientation of society, change in the system of social values, its conceptual and worldview paradigms, which are reflected in picture of the world [3]. A change or adjustment of the system of social values is reflected in ideologically charged lexemes, which in this case are condensed, compressed incarnations, clots, nodes of ideological, political guidelines, assessments and preferences [3].

Cultural dominants in the language are objectively distinguished by sampling and studying lexical and phraseological units, precedent texts from various sources. Researchers also consider the internal form of a word to be one of the auxiliary means of studying cultural dominants in a language [2], which plays a special role in expressing culturally colored pragmatic meaning.

The focus of our attention was on words with a high degree of activity, due to the need to draw attention to the phenomenon. Ones of such striking keywords involved in modern derivational processes are the keywords COVID-19, coronavirus, pandemic. It is worth emphasizing that these lexemes instantly became international keywords.

The emergence of international key elements is a completely justified and expected process within the framework of modern word creation, since "The internationalization of the vocabulary of Slavic languages, including Russian and Czech, is manifested, on the one hand, in lexical borrowing, i.e. That is, in the intensification of the use of foreign words in them, mainly Anglicisms and Americanisms, on the other hand, in the intensification of the use of word-formation elements of foreign language origin in the process of neological nomination" [11].

The pandemic so strongly affects not only life, but also the public consciousness that it is inevitably reflected in the active mass word creation. Czech journalists noted back in April 2020 that the coronavirus is changing the Czech language, hundreds of new words have been created: Koronavirus mění češtinu. Vznikly už stovky nových slov, popisuji lingvisté (https://ct24.ceskatelevize.cz/veda/3071100-koronavirus-meni-cestinu-vznikly-uzstovky-novych-slov-popisuji-lingviste). The Academy of Sciences of the Czech Republic adds them to the Neomat database of new terms, available on the Internet (http://neologismy.cz/) ${ }^{1}$.

Similar thoughts can be found in the Russian media: Kovidiot, infodemiya $i$ samoizolyatsiya: kak koronavirus menyayet russkiy yazyk / Covidiot, infodemia and selfisolation: how the coronavirus is changing the Russian language 2 (https://mir24.tv/articles/16405665/kovidiot-infodemiya-i-samoizolyaciya-kak-

koronavirus-menyaet-russkii-yazyk); Sididomtsy i pogulyantsy: Slovar' epokhi koronavirusa. Kak izmenilsya nash yazyk iz-za pandemii / Sididomites and Walkers: A

\footnotetext{
${ }^{1}$ Examples from Czech are based on materials from the Database of excerpt material Neomat, version 3.0 (http://neologismy.cz/)

${ }^{2}$ All Russian examples are written by transliteration and have English equivalent through a slash.
} 
Dictionary of the Coronavirus Epoch. How our language has changed due to the pandemic (https://www.the-village.ru/city/city-guide/380605-slovar-koronavirusa).

As it has been already noted, most new words are created by compounding. The emergence of agglutinative composites formed without the help of a connecting vowel in Russian and Czech languages (as well as in Polish), E.I. Koryakovtseva rightly connects with the influence of the global English language [4].

Cases of the formation of complex neologisms only based on the actual Czech manufacturing bases are not noted [12].

In early 2020, when the virus was just beginning to spread across all countries, one of the most frequent sentiments that could be seen in the example of the generation of new words was skepticism. The world's population was skeptical about how large-scale and global the impact of the virus would be: Kak infopandemiya vliyayet na koronavirus. Otkuda beretsya informatsiya o rasprostranenii infektsii $i$ komu verit', vyyasnili korrespondenty "Peterburgskogo dnevnika" / How infopandemic affects the coronavirus. Where does the information about the spread of the infection come from and who to believe, the correspondents of "Petersburg Diary" found out (https://spbdnevnik.ru/news/2020-03-17/kak-infopandemiya-vliyaet-na-koronavirus) ${ }^{3}$.

The Institute of Czech language has recorded, for example, synonyms for a person who behaves irresponsibly in a pandemic situation. According to their observation, the terms koronaidiot or covidiot are used for it.

The neologism covidiot is borrowed from English by both Russian and Czech languages. This lexeme has given rise to a number of other nominations of people skeptical about what is happening: such people either completely deny the massive spread of coronavirus and its infection or are skeptical about the danger of this virus. Softer equivalents appeared in the studied languages - coronapofigist, covigist (crown, COVID + pofigist / who does not care. - Auth.).

One of the most popular models in both Russian and Czech is the agglutinative model of the formation of complex words with the first unchangeable part of the corona-/ korona-: Spasayemsya ot koronanevroza. Kak uberech' svoyu psikhiku, sovety nevrotika / We are saving ourselves from coronary neurosis. How to protect your psyche, neurotic advice (https://zen.yandex.ru/media/yarina/spasaemsia-ot-koronanevroza-kak-uberech-svoiupsihiku-sovety-nevrotika); Sem' mifov, na kotorykh derzhitsya koronapsikhoz / Seven myths that drive coronpsychosis (https://riam.tv/news/187376/sem_mifov_na_kotoryih_derjitsya_koronapsihoz.html); Virus kak oruzhiye. Kto initsiiroval koronaisteriyu? / The virus as a weapon. Who initiated the corona hysteria? (https://zen.yandex.ru/media/kalashnikov/ virus-kak-orujie-kto-iniciirovalkoronaisteriiu). V Austrálii dochází v souvislosti s coronapanikou toaletní papír. Posílat jim z Evropy humanitárni baliky je ale zcestné, bo na jižni polokouli je papír na ruličce namotán obráceně (Twitter.com, 2020); Prezident Alexandr Lukašenko tvrdí, že nejlepším lékem je pracovat, sportovat a chodit do sauny. Mluví o koronapsychóze a naznačuje, že paniku kolem nemoci si přjí nepřátelé režimu (ct24.cz, 2020); Předpovědi o hospodářských a sociálních následcich coronadeprese 2020 se predháněji svojí pochmurností a odevzdaností. Je zdravějši je nebrat na vědomí. Aby bylo jasno, netvrdím, že bychom neméli Covid-19 brát vážně. Jde o to, jestli všechna ta spektakulární opatření, která vlády přijaly proti této hrozbě, jsou přiměrená a nutná, nebo ne (vasevec.cz, 2020); Každopádně posledni kolekci jsem kompletně ani nedokončila nejspiše $z$ "koronafrustrace" a zároven̆ jsem se $k$ tomu už nechtěla vracet, takže karanténní fotky a karanténa video nabídlo jen jeji polovinu, avšak nyní z ní na podzim/zimu čerpám do prodejnich produkti̊ (harpersbazaar.cz, 2020) etc.

\footnotetext{
${ }^{3}$ All examples retain their original spelling and punctuation.
} 
It can be noted that words with the element corona-/ corono- create a whole set of new terms denoting the painful state of society, people during the 2020 pandemic.

The pandemic has led to really serious changes in the structure of the world community and seriously affected the psychological aspects of human life. It became necessary to identify a new type of fears, phobias caused by modern realities: Termin "kovidofobiya" tozhe na slukhu, khotya ofitsial'no ne priznan. Vrachi poka somnevayutsya, chto eto kakoye-to otdel'noye zabolevaniye, skoreye obychnaya mnitel'nost' / The term "covidophobia" is also on hearing, although not officially recognized. Doctors still doubt that this is some kind of separate disease, rather a common suspiciousness (https://mir24.tv/articles/16405665/kovidiot-infodemiya-i-samoizolyaciya-kak-

koronavirus-menyaet-russkii-yazyk); Koronafobie nabrala $v$ uplynulém mésíci opravdu grotesknich podob a hrdě prohlašuji, že naprostou většinu doporučení ministra zdravotnictví nedodržuji. Ano, samozřejmě si myji často a pečlivě ruce mýdlem (ostatně jako vždy); ano, telefon každý den po př́chodu domů přetřu technickým lihem nebo namydlenou houbičkou (Internet, 2020) etc.

Naturally, neologisms, formed in the epoch of the pandemic, reflect the negative sentiments of society, they highlight not only health and psychological problems, but also other basic human problems - economic, moral for example: Neuzheli $v$ godinu zakhlestnuvshego planetu koronomoriya nam ne pobyt' vo vremennom Paskhal'nom zatvore po slovu nashego Svyateyshego ottsa? / Is it possible that in the time of the coronavirus that has swept the planet, we will not be in a temporary Easter retreat at the word of our Holy Father? (https://www.pravmir.ru/test-na-lyubov-kakoj-budet-pasha-vmire-pandemii); Koronakrizis-2020: chto budet $i$ chto delat'. Stsenarii razvitiya $i$ mery ekonomicheskoy politiki / Coronacrisis 2020: what will happen and what to do. Development scenarios and economic policy measures (http://liberal.ru/lmekspertiza/koronakrizis-2020-chto-budet-i-chto-delat); Pozor!! Tento nejdéle sloužicí poslanec $v$ dolni komoře České republiky mazaně využil premiérova momentálního zaneprázdnění “coronakrizi” a operativně připravil geniální strategický plán $k$ jeho politické likvidaci! (blog.idnes.cz, 2020) etc.

Unfortunately, not only the virus itself threatens the population of any country, but also unscrupulous people who use the current difficult situation to deceive gullible citizens: Korona-moshenniki: kak doverchivykh grazhdan obmanyvayut vo vremya pandemii / Corona scammers: how gullible citizens are cheated during a pandemic (https://yandex.com/news/story/Korona-moshenniki_kak_doverchivykh_grazhdan_ obmanyvayut_vo_vremya_pandemii); Koronazhuliki. Razumeyetsya, na volne etoy istorii $s$ koronavirusom aktivizirovalos' vsyakoye zhul'ye. V svyazi so vspyshkoy novogo koronavirusa $v$ Kitaye $v$ Runete poyavilis' ob'yavleniya o prodazhe oberegov $i$ protivogazov, zashchishchayushchikh ot etoy infektsii? / Corona crooks. Of course, in the wake of this story with the coronavirus, all kinds of crooks have intensified. In connection with the outbreak of a new coronavirus in China, there were advertisements on the sale of amulets and gas masks that protect against this infection on the RuNet? (https://www.exler.ru/blog/ koronazhuliki.htm); I teper' eto tselaya industriya "koronazhulikov" / And now it's a whole crown rogue industry (https://ren.tv/news/x/691989komu-covid-a-komu-mat-rodnaia-kak-moshenniki-obmanyvaiut-rossiian); Nadaci chtěji obrat koronapodvodníci. Pětaosmdesát procent žádostí je falešná \# Až 85 \% žádostí o "korona” pomoc, které reši Patron détí, je podvodná (seznamzpravy.cz, 2020); Policie zatkla člověka, který prodával respirátor za 1000 korun. Média ho nazvala koronašmejdem (Reflex, 2020) etc.

When analyzing existing and emerging words, attention is drawn to the difference in the spelling of Russian neologisms (continuous and hyphenated spelling) with a uniform continuous spelling of Czech neoderivatives. The external appearance of Russian 
neologisms is also distinguished by the fact that in writing new lexemes it is possible to combine two alphabets - Cyrillic and Latin, which in general illustrates one of the active processes taking place in modern Russian graphics.

A significant number of neologisms express an ironic, joking attitude towards everything that happens - metaphorical images of a circus, carnival appear: Ucheniya konchilis': 26 maya Putin "ob'yavil parad”, a 27 maya Minzdrav prikazal svorachivat' COVID-tsirk / The exercises ended: on May 26, Putin "announced a parade" and on May 27, the Ministry of Health ordered the COVID circus to close (https://yurasumy.livejournal.com/2725660.html); Koronacirkus či koronavirvál, během pandemie narozená koroňata a coby následek omezeni obvyklých aktivit pak napřesrok nová generace koroniálů. Anebo také roušičky sehnuté nad šicími stroji, naroušitel či rouškokaz pohoršujicí spoluobčany pohybem na veřejnosti bez ústenky... (Respekt, 2020) etc. In the last example, it can be noted that a number of neologisms of the same root are included in the text, which create the lexical-semantic field of the pandemic and are a vivid means of word-building game. On the basis of the Czech lexeme rouška 'mask' hybrid neoderivatives are created: roušičky - rouška + šičky (mask + seamstress); naroušitel rouška + narušitel (mask + intruder); rouškokaz - rouška + stávkokaz (mask + strikebreaker).

In the future, it seems promising to consider the entire lexical and semantic field of the coronavirus pandemic.

Hybrid neologisms have a special expression, since they condense several meanings in themselves and additionally attract attention by their consonance with conventional words, their unusual structure: Koronatriotizm (korona + patriotizm. - Auth) ili TRET'YA MOROVAYA. Koronavirus zagadochnogo proiskhozhdeniya izmenil ne tol'ko lik planety, no $i$ pokhody $k$ ponimaniyu patriotizma $v$ deystvii, konkretnogo, adresnogo patriotizma. Adresaty - eto zarazivshiyesya i vrachi / Coronatriotism (crown + patriotism. - Auth) or THIRD MOROVA. The coronavirus of mysterious origin has changed not only the face of the planet, but also the approach to understanding patriotism in action, concrete, targeted patriotism. Addressees are infected and doctors (https://zen.yandex.ru/media/id/5e38302cd810225b7ccf7503/koronatriotizm-ili-tretiamorovaia); Kovidarnost' (kovid + solidarnost'. - Auth.) - zhizn' i volonterstvo v epokhu pandemii / Covidarity (covid + solidarity. - Auth.) - life and volunteering in the era of a pandemic (https://covidarnost.com/); Stejně jako kretenismus se karantenismus (karanténa + kretenismus. - Auth.), v rámci celého světa, vyznačuje různě silným lokálním výskytem despocie. $V$ mistech s nejdelši dobou nadvlády cíleně způsobuje poškozování inteligence, motoriky a němoty postižených (blog.idnes.cz, 2020); ... věř́m, že jednou budu vnoučatům vyprávět, jak jsem čtyricátiny slavila v celostátní karanténě, šila roušky, pila nejlevnějši lihoviny a pritom byla nečekaně štastná. Hepy coronarozeniny (corona + narozeniny. Auth.) tů mí (seznamzpravy.cz, 2020) etc.

It should be noted that hybridization as an occasional way of word production is gradually turning into an actively operating method of modern word production [13].

In this way,"It is the derivational processes and relations that reflect the ways of assimilating knowledge and experience with the help of root and affixal morphemes that are relevant for a given era to objectify new concepts and connections "[14].

\section{Conclusion}

The considered array of neologisms indicates that the authors, when creating new words, use both typical and non-standard methods of word formation.

Words created using generic methods are intuitive. Words created by atypical methods require careful analysis to understand the underlying meaning. 
Hybrid neologisms are characterized by their causticity, causticity, grin, orientation to a language game, capacity of lexical meaning, to a greater extent than neologisms created according to standard models.

The absence of strict censorship, the courage and creativity of the authors, the wordformation capabilities of the Russian and Czech languages contribute to the spread of neologisms on the Internet and mass media in general.

"Thus, the presence of similar factors predetermines the similarity of their linguistic implementation in closely related languages" [15]. As we can see, the desire to influence public consciousness is increasingly becoming the dominant communicative attitude, which determines the conditions of communication between the journalist and the audience and affects the qualitative characteristics of the media text, in particular, this is manifested in media word creation. The global trend towards an increase in the expressiveness of the texts of the Russian and Czech mass media is explained by the attitude to influence. This feature is clearly reflected in the author's word-creation, the creation of new formations.

The results of the study testify to the social orientation and evaluative nature of neologisms in the mass media, which reflect the specifics of the linguistic picture of the world of various representatives of modern Russian and Czech society. In the future, it seems expedient to observe the functioning of neologisms in mass media texts in order to identify the principles of reflection in them of socio-cultural facts of modern reality.

\section{Acknowledgments}

This work was supported by the Russian Foundation for Basic Research, grant No. 20-51223003.

This paper was financially supported by the Russian Foundation for Basic Research, grant No. 20-012-22046.

\section{References}

1. E.A. Zemskaya, Active processes of modern word production, in Russian language of the late XX century, 90-141 (2000)

2. V.I. Karasik, Cultural dominants in the language, in Language circle: personality, concepts, discourse, 166-205 (2002)

3. P. Chervinskiy, The ideological component in the interpretation of lexical meaning, in Z zagadnień semantyki i stylistyki tekstu, 13-22 (2010)

4. E.I. Koryakovtseva, Essays on the language of modern Slavic media (semantic-wordformation and linguocultural aspects) (2016)

5. E. Bialek, As they say in the Russian media. Norm and Usus (2004)

6. A.D. Yudina, Occasionalisms on the pages of periodicals, in Russian speech, 5, 14-17 (1999)

7. E.M. Markova, Lexicons of modern Slavic languages: similarities and differences, in Philology and culture, №4(42), 103, (2015).

8. M.N. Volodina, The language of the media as a reflection of linguistic reality, in Russian language: historical destinies and modernity: III International Congress of Russian Language Researchers: Proceedings and Materials, 40-41 (2007). 
9. V.N. Telia, Russian phraseology. Semantic, pragmatic and linguocultural aspects, (1996)

10. E.E. Agaronova, On some features of actualization of evaluative dominants in the language of modern newspapers, in Lomonosov readings (2001) URL: http://lib.socio.msu.ru/l/library

11. J. Gazda, Internationalization word-formation tendencies in modern Russian and Czech languages, in Sborník prací Filozofické Fakulty Brněnské Univerzity, A 49, 128 (2001)

12. O. Martincova, Neologizmy v dnešní češtině (2005)

13. N.A. Nikolina, Types and functions of contaminated formations in modern Russian speech, in Proceedings of the Institute of the Russian language, 13, 288-295 (2017).

14. E.I. Koryakovtseva, Internationalization, democratization and "mediatization" of Slavic languages in the context of globalization (word-formation aspect), in Globalizacja a jezyki slowianskie. Globalization and Slavic languages. Papers dedicated to the XVI International Congress of Slavist, Siedlce, 14 (2018)

15. G.P. Neshchimenko, Comparative study of Slavic languages and its significance for forecasting and development of the language system, in Aktualne problemy komparatystiki slowianskiej i teoria i metodologia badan lingwistycznych, Siedlce, 43 (2010) 